\title{
KIERUNKI BADAŃ NAD ORGANIZACYJNYM ODUCZANIEM SIE
}

DOI: $10.33141 /$ po.2020.07.02

Regina Lenart-Gansiniec
Przegląd Organizacji, Nr 7(966), 2020, s. 12-19

www.przegladorganizacji.pl

๑ Towarzystwo Naukowe Organizacji i Kierownictwa (TNOiK)

\section{Wprowadzenie}

$\mathbf{Z}$ łożone zjawiska społeczne, gospodarcze oraz technologiczne mają wpływ na funkcjonowanie współczesnych organizacji i sprawiają, że dotychczasowe sposoby zarządzania wymagają redefinicji. Wynika to z faktu, że nadmierne przywiązanie organizacji do tradycyjnych obszarów działania oraz praktyk zarządzania może ograniczać zdolność organizacji do konkurowania i wygrywania, a wykorzystanie posiadanych kompetencji i zasobów wiedzy będzie miało efekt odwrotny do zamierzonego (Dixon, 1992). Dodatkowo, kluczowe kompetencje mogą okazać się źródłem porażki organizacji i stać się „kluczowymi nieustępliwościami” (core rigidities) (Leonard-Barton, 1992). W odpowiedzi organizacje powinny „nauczyć się zapominać” (Hamel, Prahalad, 1993) i świadomie odrzucać wiedzę bazową oraz tworzyć nową. W literaturze wskazuje się, że organizacyjne oduczanie się jest niezbędne do tego, aby organizacje mogły rozpoznawać zmiany, uczyć się, przetrwać oraz konkurować (Meziaz i in., 2001). Organizacyjne oduczanie się odnosi się do odrzucenia wcześniej przyjętych procedur, wiedzy, norm, wartości, aby zrobić miejsce dla nowych (Tsang, Zahra, 2008), a także usunięcia zbędnych i szkodliwych dla organizacji elementów z pamięci organizacyjnej (Akgün i in., 2003).

W ciągu ostatnich kilku lat organizacyjne oduczanie się przyciąga coraz większą uwagę badaczy (Klammer, Gueldenberg, 2019). B. Hedberg (1981) był pierwszym z uczonych, który powiązał organizacyjne oduczanie się $\mathrm{z}$ kontekstem organizacyjnym. Początkowo pojęcie to było łączone z organizacyjnym uczeniem się (Huber, 1991). Obecnie postuluje się uznanie organizacyjnego oduczania się jako odrębnej koncepcji (Tsang, Zahra, 2008).

Dotychczasowe badania nad organizacyjnym oduczaniem się były prowadzone z różnych perspektyw i nurtów zarządzania (Akgün i in., 2007; Becker, 2018; Klammer i in. 2019; Sinkula, 2002; Starbuck, 2017; Tsang, Zahra, 2008). Nadal jednak obserwuje się trudności związane z definiowaniem czy operacjonalizacją (Becker, 2010; Hislop i in., 2013; Tsang, 2017; Starbuck, 2017). Co więcej, postuluje się konieczność dalszych badań nad organizacyjnym oduczaniem się (Klammer, Gueldenberg, 2019), ponieważ jest ono jednym $\mathrm{z}$ najmniej wyjaśnionych zjawisk organizacyjnych (Akhshik, 2014).

Mając na uwadze powyższe, celem artykułu jest identyfikacja istniejących strumieni badań oraz wyłaniających się kierunków badań nad organizacyjnym oduczaniem się przy wykorzystaniu systematycznego przeglądu literatury. Zaproponowano następujące dwa pytania badawcze:

P1. Jaki jest obecny stan badań nad organizacyjnym oduczaniem się?

P2. Jakie są kierunki przyszłych badań nad organizacyjnym oduczaniem się?

\section{Metoda badawcza}

W celu identyfikacji wyłaniających się kierunków badań nad organizacyjnym oduczaniem się przeprowadzono systematyczny przegląd literatury zgodnie z wytycznymi PRISMA (Moher i in., 2009). Metodyka systematycznego przeglądu literatury składa się z czterech etapów, takich jak: 1) określenie celu badań, 2) wyłonienie literatury przedmiotu, 3) zastosowanie technik analizy bibliometrycznej i analizy treści oraz 4) opracowanie raportu.

Przegląd literatury został ograniczony do artykułów naukowych, które zostały opublikowane w ciągu ostatnich 40 lat. Analiza objęła lata 1981-2020, ponieważ koncepcja organizacyjnego oduczania się została wprowadzona w 1981 roku. Wybrano tak długi okres ze względu na potrzebę uwzględnienia najistotniejszych badań w podjętym temacie. Literatura przedmiotu została wyłoniona, opierając się na przeszukiwaniu zagranicznych baz danych, takich jak: Ebsco, Emerald, Elsevier, ProQuest, Scopus i Web of Science.

Aby zapewnić ciągłość badań (Tranfield i in., 2003), $\mathrm{w}$ pierwszej kolejności dokonano wstępnego przeszukiwania baz danych. Kryterium filtrowania były słowa kluczowe „organization* AND unlearn ${ }^{\star ”}$. To wstępne wyszukiwanie przyniosło 24558 trafień. Dodatkowo, w celu zniwelowania potencjalnych ograniczeń spowodowanych przez kryterium wyszukiwania, przegląd literatury rozszerzono do czasopism znajdujących się w pierwszej dziesiątce czasopism akademickich z zakresu zarządzania wiedzą i kapitałem intelektualnym (Serenko, Bontis, 2017). Przeszukiwań dokonano w następujących czasopismach: Journal of Knowledge Management, Journal of Intellectual Capital, The Learning Organization, Knowledge Management Research \& Practice, Knowledge and Process Management: The Journal of Corporate Transformation, VINE: The Journal of Information and Knowledge Management Systems, International Journal of Knowledge Management, 
Journal of Information and Knowledge Management, International Journal of Learning and Intellectual, Capital, International Journal of Knowledge and Learning. Kolejno na zidentyfikowane artykuły nałożono następujące ograniczenia: 1) pełnotekstowe, recenzowane artykuły naukowe (książki, rozdziały w książkach, materiały konferencyjne, recenzje, wstępy redakcyjne zostały wyłączone), 2) słowa kluczowe „organization* AND unlearn ${ }^{\star}$ " w tytule, streszczeniu, 3) kategoria „biznes, ekonomia, zarządzanie”. Następnie dokonano przeglądu i weryfikacji abstraktów, co pozwoliło na zawężenie bazy publikacji do tych, które koncentrują się stricte na organizacyjnym oduczaniu się z pespektywy nauk o zarządzaniu i jakości. Dalszą analizą objęto 63 publikacje wyłonione, opierając się na zagranicznych bazach danych, oraz 25 publikacjach wyłonionych po przeszukiwaniu recenzowanych czasopism naukowych. Szczegółowe wyniki poszczególnych etapów sekcji prezentuje rysunek 1. W kolejnym kroku zakodowano 88 publikacji z uwzględnieniem wykorzystanych definicji, zastosowanych metod badawczych, nurtów badawczych oraz rekomendacji innych badaczy.

\section{Wyniki systematycznego przeglądu literatury}

\section{Organizacyjne oduczanie się: horyzont czasowy}

7 godnie z przyjętymi etapami i kryteriami selekcji ar$\angle$ tykułów, zidentyfikowano 88 publikacji. Na rysunku 2 pokazano linię liczby prac opublikowanych w latach 1981-2020. Jak wynika z analizy danych, liczba publikacji poświęconych organizacyjnemu oduczaniu się stale rośnie od końca lat 90. Pokazuje to, że organizacyjne oduczanie się jest rozwijającym się obszarem badań. Wprawdzie w latach 2005-2006 znaleziono tylko 4 publikacje, ale już w 2006 roku odnotowano zdecydowany wzrost ich liczby do 9. Najdynamiczniejszy wzrost liczby publikacji zauważono w latach 2017-2019. Tendencję przyrostową potwierdza również ekstrapolacja trendu, która wskazuje oczekiwany w przyszłości wzrost liczby publikacji poświęconych organizacyjnemu oduczaniu się. Przyjmując, że tendencja wzrostu liczby publikacji znajdzie swoją kontynuację w latach 2020-2022, to przewiduje się, że w 2022

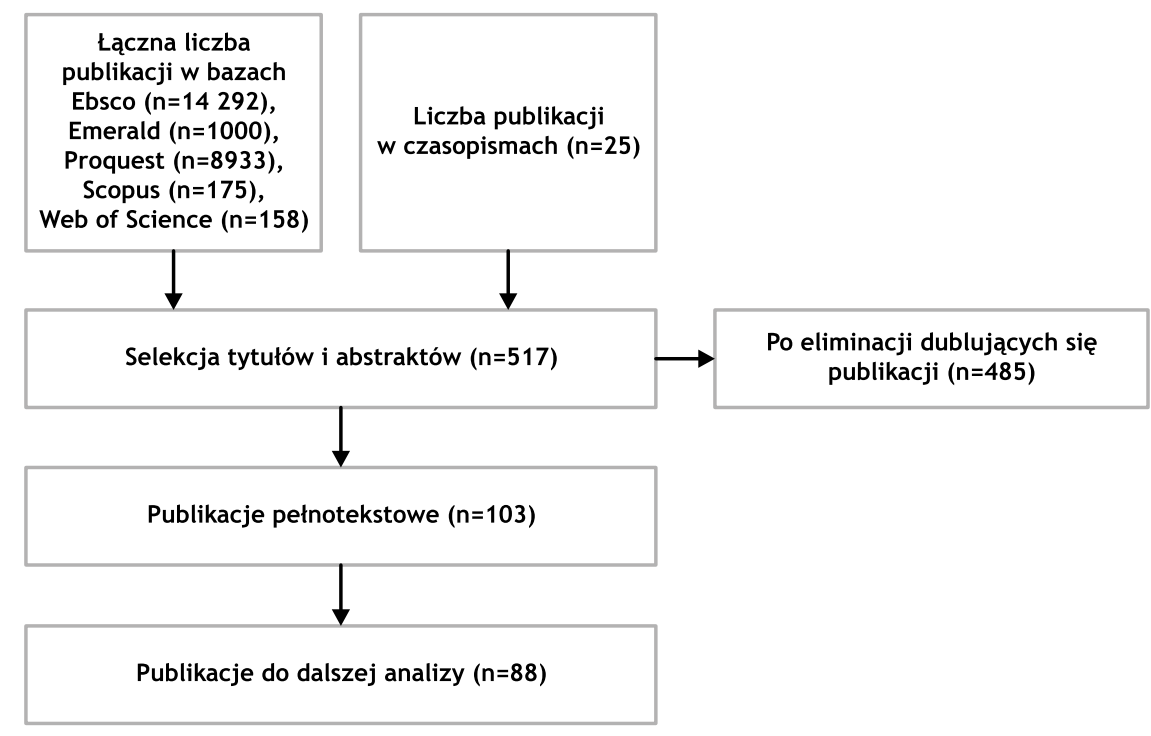

Rys. 1. PRISMA - etapy systematycznego przeglądu literatury Źródło: opracowanie wtasne

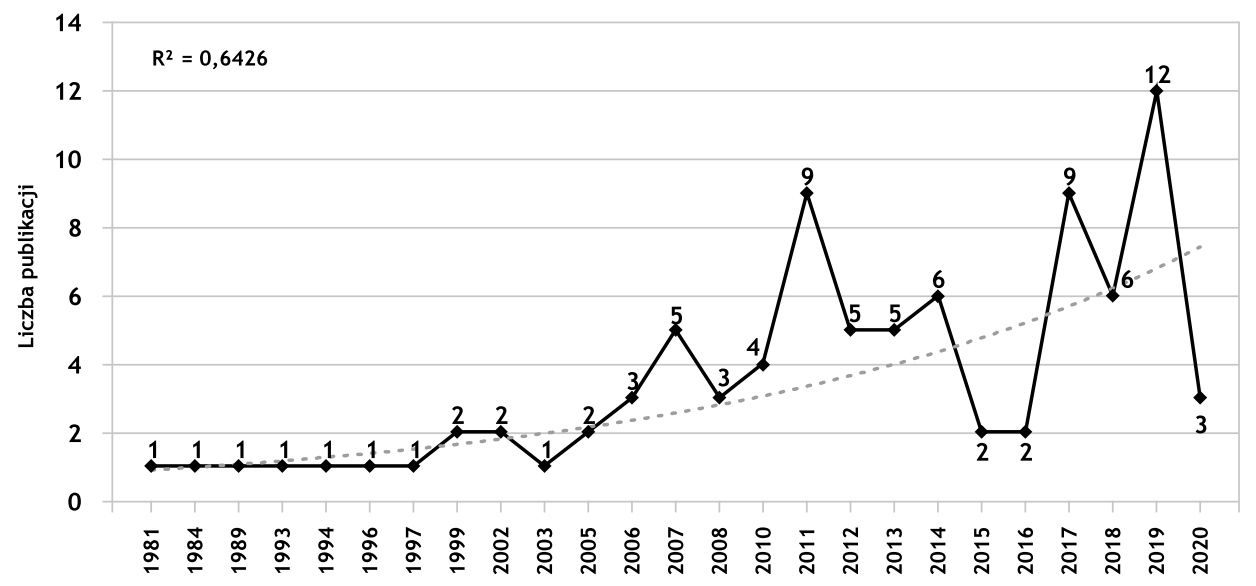

Rys. 2. Liczba publikacji dotyczących organizacyjnego oduczania się w latach 1981-2020 Źródto: opracowanie własne 
roku opublikowanych zostanie 32 artykuły, co w $60 \%$ wyjaśnia funkcja liniowa $\left(\mathrm{R}^{2}=0,6426\right)$.

\section{Organizacyjne oduczanie się: metody badawcze}

W 88 zidentyfikowanych publikacjach 40 artykułów ma charakter empiryczny $(45,45 \%)$. W 32 z 40 publikacji jako metodę badawczą wybrano metodę badań ankietowych. Autorzy rozwijają własne narzędzia pomiarowe (Becker, 2010; Cegarra-Navarro, Sánchez-Polo, 2008; Lee, Sukoco, 2011; Sheaffer, Mano-Negrin, 2003) lub adaptują już istniejące (Akgün i in., 2003; Akgün i in., 2007; Casillas i in., 2010; Cegarra, Navarro, Dewhurst, 2006; Wang i in., 2013). W dotychczasowych badaniach wykorzystywano zazwyczaj siedmiostopniową skalę Likerta (24 razy). Pomiaru dokonywano także przy wykorzystaniu sześciostopniowej (2 razy), dziesięciostopniowej (3 razy) oraz pięciostopniowej (3 razy) skali Likerta. Badania były prowadzone również $\mathrm{z}$ wykorzystaniem metod jakościowych, w tym: studia przypadków (4 publikacje) oraz wywiady (1 publikacja). Badacze sięgali również po metody mieszane (3 publikacje). W szczególności te ostatnie są rekomendowane do prowadzenia badań nad organizacyjnym oduczaniem się (Becker, 2005; Rezazade Mehrizi, Lashkarbolouki, 2016). Połączenie metod ilościowych i jakościowych może przyczynić się do lepszego zrozumienia mechanizmu i złożoności oduczania się (Fetters, Molina-Azorin, 2017). Dotychczas prowadzono badania przekrojowe nad organizacyjnym oduczaniem się, co nie pozwoliło stwierdzić, czy zidentyfikowane związki przyczynowo-skutkowe mogą się zmieniać i zyskać lub stracić na znaczeniu (Mieres i in., 2012). Z przeprowadzonej analizy wynika jednak, że zasadne jest prowadzenie w przyszłości podłużnych badań nad organizacyjnym uczeniem się (Mieres i in., 2012), co wynika z faktu, że czas jest katalizatorem indywidualnego oduczania się (Hislop i in., 2013). Badania podłużne nad oduczaniem się mogą także umożliwić obserwację zmieniających się wzorców zachowań w organizacji (Cepeda-Carrión i in., 2011; Lyu i in., 2020), uwzględniających kontekst oduczania się (Cegarra-Navarro i in., 2014; Cepeda-Carrión i in., 2011), identyfikację czynników ułatwiających oduczanie się na poziomie indywidualnym (Hislop i in., 2013) oraz zrozumienie procesu oduczania się (Martelo-Landroguez i in., 2018).

\section{Organizacyjne oduczanie się: poziomy analizy}

Badacze analizowali organizacyjne oduczanie się na różnych poziomach, takich jak: organizacyjnym (28 publikacji), grupowym (3 publikacje) oraz indywidualnym (9 publikacji). Poziom organizacyjny oduczania się wydaje się najlepiej rozpoznanym w literaturze. Większość publikacji analizuje oduczanie się z uwzględnieniem pamięci organizacyjnej (Becker, 2005), kultury organizacyjnej (Sinkula, 2002), reorientacji wartości i norm organizacyjnych, struktur poznawczych, modeli mentalnych oraz dominującej logiki (Cepeda-Carrion i in., 2012; Cegarra-Navarro i in., 2013; 2015).

Organizacyjne oduczanie się na poziomie grupowym było rzadko analizowane. Najczęściej badania koncentro- wały się wokół znaczenia oduczania się dla pracy zespołowej, improwizacji zespołowej (Akgün i in., 2007), zmiany przekonań i procedur zespołu oraz podważania istniejących poglądów (Akgün i in., 2006) dla opracowania nowego produktu (Lee, Sukoco, 2011). A.E. Akgün i inni (2006) postulują, że wywoływanie przez menedżerów kryzysów $\mathrm{w}$ organizacji ma znaczenie dla grupowego oduczania się. Dodatkowo w literaturze analizowano znaczenie refleksyjności zespołu dla oduczania się całego zespołu (Lee, Sukoco, 2011).

Badacze prowadzili badania nad oduczaniem się $\mathrm{z}$ poziomu indywidualnego (Becker, 2010; Becker, 2008; Cegarra-Navarro, Sánchez-Polo, 2008a; Hislop i in., 2013; de Holan, Nelson, 2004; Sinkula, 2002), w szczególności poszukiwali odpowiedzi na pytania, w jaki sposób pracownicy oduczają się oraz co sprawia, że tego dokonują. Y. Zhao i inni (2013) uważają, że indywidualne oduczanie się jest wyzwalane przez osobistą motywację i reakcję na zmiany pojawiające się w otoczeniu organizacji. Z kolei D. Hislop i inni (2013) stwierdzają, że indywidualne oduczanie się stanowi warunek grupowego i organizacyjnego oduczania się. Dodatkowo, indywidualne oduczanie się jest istotne w szczególności w kontekście organizacji dojrzałych, co wynika z konieczności pozbycia się nieodpowiednich do sytuacji czy też przestarzałych procedur i zachowania (Sinkula, 2002).

\section{Organizacyjne oduczanie się: obszary tematyczne}

Wykorzystując analizę frekwencyjności, stwierdzono, że istniejące badania dotyczące organizacyjnego oduczania się koncentrują się na następujących obszarach tematycznych: antecedencje ( 7 publikacji), proces ( 9 publikacji) oraz znaczenie organizacyjnego oduczania się (24 publikacje). Przykładowo, B. Hedberg (1981) wskazuje, że wśród czynników decydujących o organizacyjnym oduczaniu się można wskazać na problemy w organizacji. K. Becker (2010) podkreśla istotność tworzenia świadomości i poczucia potrzeby odrzucania dotychczasowych procedur i zasad. Zdaniem A.E. Akgün i innych (2006), uświadomienie takiej potrzeby może nastąpić wtedy, gdy organizacja znajdzie się $\mathrm{w}$ sytuacji kryzysowej lub zamierza wdrożyć nową wiedzę. Wejście na nowe rynki (Casillas i in., 2010) jest uznane w literaturze za czynnik uzasadniający organizacyjne oduczanie się. Warto wreszcie zauważyć, że turbulencja otoczenia dostrzegana jest jako wspólny mianownik wielu prac poświęconych organizacyjnemu oduczaniu się (Akgün i in., 2006; Akgün i in., 2007; Lyu i in., 2020; Sinkula, 2002; Wong, Lam, 2012). W szczególności zwraca się uwagę na złożoność otoczenia, szybkość zmian w nim zachodzących, intensywność i nowość zmian, w tym intensywność konkurencji (Sinkula, 2002), presję ze strony klientów (Sinkula, 2002) oraz interesariuszy (Sinkula, 2002). Nie bez znaczenia jest również orientacja przedsiębiorcza (Lyu i in., 2020).

Organizacyjne oduczanie się jest procesem, na który składa się szereg działań (Easterby-Smith, Lyles, 2011; Hedberg, 1981; Wong, Lam, 2012). Przykładowo, J.G. Cegarra-Navarro i inni (2014) zidentyfikowali trzy podpro- 
Tabela 1. Rekomendowane kierunki badań nad organizacyjnym oduczaniem się

\begin{tabular}{|c|c|}
\hline Poziom analizy & Autor/autorzy \\
\hline \multicolumn{2}{|c|}{ Organizacyjny } \\
\hline Znaczenie oduczania się dla zrównoważonego rozwoju & Burkšienè, 2016 \\
\hline Znaczenie oduczania się dla adaptacji organizacyjnej & Kluge i in., 2019 \\
\hline Znaczenie oduczanie się dla radykalnych innowacji & Yang i in., 2014 \\
\hline Znaczenie oduczania się dla zdolności absorpcyjnej & Casillas i in., 2010 \\
\hline Znaczenie oduczania się dla elastyczności strategicznej & Wang $\mathrm{i}$ in., 2013; Zhao, Wang, 2020 \\
\hline Znaczenie oduczania się dla wyników organizacji & Lyu i in., 2020; Wensley, Cegarra-Navarro, 2015 \\
\hline Znaczenie oduczania się dla współtworzenia wartości klienta & Mieres i in., 2012; Wensley, Cegarra-Navarro, 2015 \\
\hline Przebieg oduczania się & Becker, 2005; Hislop i in., 2014 \\
\hline Identyfikacja czynników warunkujących oduczanie się & Becker, 2005; Becker, 2010 \\
\hline Identyfikacja czynników wspierających oduczanie się & $\begin{array}{l}\text { Cepeda-Carrion i in., 2012; Cegarra-Navarro, Wensley, 2019; } \\
\text { Cegarra-Navarro i in., 2011; Lyu i in., 2020; Peschl, 2019; } \\
\text { Wong i in. 2012; Grisold i in., 2017; Kluge i in., } 2019\end{array}$ \\
\hline Rola menedżerów & $\begin{array}{l}\text { Akgün i in., 2007; Cegarra-Navarro i in., 2016; } \\
\text { Cegarra-Navarro i in., 2010; Cegarra-Novarro i in., 2013; } \\
\text { Gutiérre i in., 2015; Nystrom, Starbuck, 1984; Kluge i in., } 2019\end{array}$ \\
\hline Znaczenie przywództwa etycznego dla organizacyjnego oduczania się & Usman i in., 2018; Kluge i in., 2019 \\
\hline Znaczenie kontekstu kulturowego dla oduczania się & $\begin{array}{l}\text { Cegarra-Navarro i in., 2016; Cegarra-Navarro, Sánchez-Polo, 2007; } \\
\text { Cegarra-Navarro i in., 2011; Navarro, Moya, 2005; } \\
\text { Scheaffer, Mano-Negrin, } 2003\end{array}$ \\
\hline Uwzględnienie zmiennych kontrolnych (wielkość organizacji, własność) & Martelo-Landroguez i in., 2018; Ruiz i in., 2017; Wang i in., 2017 \\
\hline Oduczanie się podczas wdrażania nowych technologii & $\begin{array}{l}\text { Becker, 2010; Cegarra-Navarro i in., 2014; Yang i in., 2014; } \\
\text { Pighin, Marzona, } 2011\end{array}$ \\
\hline Oduczanie się w różnego rodzaju projektach innowacyjnych & Akgün i in., 2007; Mieres i in., 2012; Ramírez i in., 2017 \\
\hline Identyfikacja antecedencji & Akgün i in., 2007 \\
\hline Mentoring jako czynnik wzmacniający organizacyjne oduczanie się & McKeown, 2012 \\
\hline Mediacyjna rola kompatybilności wiedzy & Wang i in., 2017 \\
\hline Mediacyjna rola integracji społecznej & Yildiz, Fey, 2010 \\
\hline Znaczenie niepewności otoczenia dla oduczania się & Akgün i in., 2007; Zhao i in., 2013 \\
\hline Znaczenie inercji wiedzy, pamięci, kultury organizacyjnej dla oduczania się & Becker, 2005 \\
\hline Znaczenie technologii dla oduczania się & Kluge i in., 2019 \\
\hline \multicolumn{2}{|c|}{ Grupowy } \\
\hline Znaczenie zespołu dla opracowania nowych produktów & Lee, Sukoco, 2011 \\
\hline Identyfikacja czynników wspierających oduczanie się zespołu & Cegarra, Wensley, 2019; Peschl, 2019 \\
\hline Sposoby oduczania się zespołów & Akgün i in., 2006; Akgün i in., 2007; Volland, 2019 \\
\hline \multicolumn{2}{|c|}{ Indywidualny } \\
\hline Znaczenie indywidualnego oduczania się dla zmian organizacyjnych & Hislop i in., 2014 \\
\hline Znaczenie indywidualnego oduczania się dla innowacji organizacyjnych & Wang i in., 2013 \\
\hline Konsekwencje behawioralne oduczania się & Akgün i in., 2007 \\
\hline Sposoby oduczania się jednostek & Becker, 2010; Hislop, 2014 \\
\hline Identyfikacja czynników wspierających oduczanie się & $\begin{array}{l}\text { Cegarra-Navarro, Wensley, 2019; Cegarra-Navarro, Sánchez-Polo, 2008a; } \\
\text { Lee, Sukoco, 2011; Peschl, } 2019\end{array}$ \\
\hline Kryzys i lęk jako antecedencje oduczania się & Akgün i in., 2006 \\
\hline Znaczenie wieku, płci, stażu pracy, rodzaju branży dla oduczania się & Becker, 2005 \\
\hline
\end{tabular}

Źródto: opracowanie własne 
cesy, takie jak: świadomość, porzucenie oraz ponowne uczenie się. W literaturze wskazuje się także na percepcję jednostek, rutyny, założenia, nawyki oraz modele mentalne (Azmi, 2008; Zhao i in., 2013). Inni uznają, że organizacyjne oduczanie się koncentruje się na odrzucaniu przestarzałej wiedzy na rzecz nowej (Cepeda-Carrion i in., 2012; Sherwood, 2000; Yildiz, Fey, 2010). Organizacyjne oduczanie się jest także procesem uznania przestarzałej wiedzy i odrzucenia jej w celu dostosowania się do nowych wymagań (Becker, 2007).

\section{Organizacyjne oduczanie się: znaczenie}

W literaturze sugeruje się, że organizacyjne oduczanie się może stanowić warunek wstępny organizacyjnego uczenia się (Wang i in., 2013). Organizacyjne oduczanie się umożliwia tworzenie i zastosowanie nowej wiedzy (Cegarra-Navarro i in., 2013), jej transfer (Xiangyang i in., 2017) oraz usunięcie $\mathrm{z}$ organizacji przestarzałej wiedzy (Cegarra-Navarro i in., 2011). Dzięki temu zwiększa tzw. korytarz wiedzy, co oznacza percepcję jednostki w stronę poszukiwania nowej wiedzy o charakterze komplementarnym do dotychczas posiadanej wiedzy (Ortega-Gutierrez i in., 2015). Organizacyjne oduczanie się pozwala organizacji aktywować zdolność absorpcyjną (Cepeda-Carrión i in., 2011; 2012; Cegarra-Navarro i in., 2014; Wensley, Cegarra-Navarro, 2015).

W obszarze nauk o zarządzaniu i jakości organizacyjne oduczanie się jest postrzegane jako zmienna niezależna (32 publikacje) wywołująca internacjonalizację (Casillas i in., 2010), kształtująca kapitał relacyjny, kapitał klienta (Cegarra-Navarro, Sánchez-Polo, 2008b) oraz zielony kapitał (Martelo-Landroguez i in., 2018). Organizacyjne oduczanie się ma także znaczenie dla tworzenia kultury work-life balance (Cegarra-Navarro i in., 2016), poprawy innowacyjności (Leal-Rodríguez i in., 2015), wartości dla klienta (Sinkula, 2002), jakości usług (Cepeda-Carrión i in., 2011), rozwoju nowych produktów (Akgün i in., 2007; Lee, Sukoco, 2011), wydajności organizacji (Leal Rodríguez i in., 2015; Mieres i in., 2012), elastyczności strategicznej (Wang i in., 2013), osiągania sukcesu organizacyjnego (Wong, Lam, 2012) oraz poprawy wyników (de Holan, 2011). Dotychczasowy dorobek naukowy wskazuje, że organizacyjne oduczanie się ułatwia i katalizuje zmiany organizacyjne (Akgün i in., 2007; Becker, 2010; de Holan, 2011; Hislop i in., 2013; Meziaz i in., 2001; Tsang, Zahra, 2008; Xiangyang i in., 2017).

\section{Organizacyjne oduczanie się: rekomendacje dotyczące przyszłych badań}

Analiza dotychczasowych publikacji teoretycznych i badań empirycznych wskazuje, że nie są one wolne od ograniczeń poznawczych oraz metodyczno-metodologicznych. Synteza powyższych rozważań oraz sformułowanych rekomendacji pozwala wyłonić szczegółowe wytyczne co do przyszłych kierunków badań (tab. 1). Taki przegląd pozwoli na redukcję prowadzonych wcześniej badań, natomiast tworzenie nowej wiedzy przyczyni się do zapełnienia zidentyfikowanych luk poznawczych oraz badawczych
Podsumowując, obecny stan wiedzy pozwala na stwierdzenie o konieczności prowadzenia badań nad organizacyjnym oduczaniem się. Zgodnie $\mathrm{z}$ rekomendacjami zamieszczonymi w literaturze przedmiotu, przyszłe badania o charakterze teoriopoznawczym należy prowadzić z uwzględnieniem wszystkich trzech poziomów oduczania: organizacyjnego, grupowego oraz indywidualnego. Postuluje się także identyfikację związków pomiędzy poszczególnymi poziomami (Becker, 2005). W tym ujęciu wielopoziomowe badania empiryczne nad organizacyjnym oduczaniem się mogą przyczynić się do rozpoznania zależności, jakie zachodzą pomiędzy poszczególnymi poziomami, co pozwoli na lepsze zrozumienie znaczenia oduczania się dla organizacji (Akhshik, 2014; Becker, 2005). Obecnie ustalenia dotyczące czynników organizacyjnego oduczania się są niekompletne. Na przykład, przeprowadzone studium przypadku wskazuje na siedem czynników wspierających oduczanie się na poziomie indywidualnym (Becker, 2010), ale uzyskane wyniki nie pozwalają na generalizację wyników. Analogicznie, dostępne badania identyfikują czynniki wspierające oduczanie się, ale uzyskane wyniki nie pozwalają na generalizację wyników (McKeown, 2012). Rodzi więc to potrzebę dalszych, pogłębionych i poszerzonych badań nad organizacyjnym oduczaniem się.

\section{Podsumowanie}

$\mathbf{S}$ ynteza dotychczasowych rozważań badawczych pozwala na stwierdzenie, że organizacyjne oduczanie się cieszy się coraz większym zainteresowaniem wśród badaczy. Trzeba jednak podkreślić stosunkowo wczesny etap rozwoju badań w tym zakresie. Pomimo upływu 40 lat od daty ukazania się publikacji popularyzującej organizacyjne oduczanie się nadal liczba publikacji jest niewielka. Dotychczas badacze zazwyczaj analizowali organizacyjne oduczanie się w kontekście jego wpływu na istotne w naukach o zarządzaniu i jakości zmienne, przy czym najczęściej w analizach uwzględniali poziom organizacyjny. Poza tym analiza literatury wykazała, że ponad $45 \%$ publikacji dotyczących organizacyjnego oduczania się ma charakter empiryczny z przewagą badań jakościowych. Większość istniejących projektów badawczych sięgało po ankietowanie jako metodę badawczą. Badacze wykorzystywali istniejące instrumenty pomiarowe lub rozwijali własne. Zazwyczaj dotychczasowe badania miały charakter przekrojowy, gdzie wykorzystywano siedmiostopniową skalę Likerta. Najczęściej badania były podejmowane w sektorach high-tech, ochrony zdrowia, informacyjnym, produkcyjnym, branży hotelarskiej oraz małych i średnich przedsiębiorstwach. Organizacyjne uczenie się analizowano z perspektywy kognitywnej, behawioralnej, społecznej, emocjonalnej oraz normatywnej. Biorąc pod uwagę liczbę artykułów, można stwierdzić, że perspektywa kognitywna była dominującą.

Dokonany systematyczny przegląd literatury stanowi przyczynek do zidentyfikowania istniejących luk badawczych w obszarze organizacyjnego oduczania się i zaproponowania przyszłych kierunków badań. Dalsze 
wysiłki poznawcze wydają się oscylować wokół sześciu zagadnień. Pierwsze dotyczy identyfikacji czynników warunkujących i wzmacniających organizacyjne oduczanie się. Generalnie, organizacyjne oduczanie się jest procesem dynamicznym, wieloaspektowym i zależnym od kontekstu organizacyjnego. Drugie zagadnienie dotyczy prowadzenia badań nad organizacyjnym oduczaniem się $\mathrm{z}$ jednoczesnym uwzględnieniem trzech poziomów: indywidualnego, grupowego oraz organizacyjnego. Identyfikacja powiązań pomiędzy poziomami pozwoli na zrozumienie w sposób całościowy wielopoziomowego i procesowego charakteru organizacyjnego oduczania się. Trzecie zagadnienie wynika z niejednoznacznej roli organizacyjnego oduczania się dla uczenia się organizacji: dalsze badania $\mathrm{w}$ tym zakresie mogą doprowadzić do wypracowania całościowego obrazu związku organizacyjne oduczania się-uczenie się oraz lepszego zrozumienia znaczenia ponownego uczenia się w związku organizacyjne oduczanie się-uczenie się. Czwarte zagadnienie dotyczy sprecyzowania roli kadry kierowniczej w organizacyjnym oduczaniu się, która dotychczas opisywana jest niejednoznacznie. Z jednej strony podkreśla się w literaturze, że kadra kierownicza może inicjować procesy oduczania się w organizacji, $\mathrm{z}$ drugiej natomiast blokować wysiłki zmierzające do oduczania się organizacji. Piąte zagadnienie dotyczy ustalenia znaczenia organizacyjnego oduczania się dla implementacji innowacji technologicznych. Innowacje technologiczne wymagają zmiany systemów, infrastruktury, praktyk i struktur organizacyjnych. Szóste zagadnienie dotyczy zdefiniowania wytycznych w zakresie operacjonalizacji oraz konstrukcji narzędzia pomiaru stosowanego w toku przyszłych badań organizacyjnego oduczania się. Wyniki systematycznego przeglądu literatury wskazują, że przyszłe badania powinny mieć charakter przekrojowy $\mathrm{i}$ być prowadzone $\mathrm{z}$ wykorzystaniem metod mieszanych i skali interwałowej - 7-stopniowej skali Likerta. Sugeruje się także uwzględnienie zmiennych kontrolnych, jak: wielkość, wiek organizacji oraz własność.

Podobnie jak w przypadku każdego innego badania, przeprowadzony systematyczny przegląd literatury nie jest pozbawiony ograniczeń. Pomimo kompleksowego charakteru systematycznego przeglądu literatury istnieje zagrożenie pominięcia niektórych publikacji. Może to wynikać z faktu, że selekcji publikacji dokonano, opierając się na dostępnych w bazach danych anglojęzycznych publikacjach pełnotekstowych, co wyeliminowało w ten sposób literaturę krajową oraz opracowania niedostępne w wersji cyfrowej. W celu zniwelowania potencjalnych ograniczeń przegląd literatury rozszerzono do czasopism z zakresu zarządzania wiedzą i kapitałem intelektualnym.

\footnotetext{
dr hab. Regina Lenart-Gansiniec, prof. uczelni Uniwersytet Jagielloński Wydział Zarządzania i Komunikacji Społecznej ORCID: 0000-0002-9379-1504 e-mail: regina.lenart-gansiniec@uj.edu.pl
}

\section{Bibliografia}

[1] Akgün A.E., Byrne J.C., Lynn G.S., Keskin H. (2007), Organizational Unlearning as Changes in Beliefs and Routines in Organizations, „Journal of Organizational Change Management", Vol. 20, No. 6, pp. 794-812.

[2] Akgün A.E., Lynn G.S., Byrne J.C. (2003), Organizational Learning: A Socio-Cognitive Framework, „Human Relations", Vol. 56, No. 7, pp. 839-868.

[3] Akgün A.E., Lynn G.S. Byrne J.C. (2006), Antecedents and Consequences of Unlearning in New Product Development Teams, „Journal of Product Innovation Management", Vol. 23, No. 1, pp. 73-88.

[4] Akhshik S.S. (2014), Organizational Unlearning: An Analytical Literature Review, „International Journal of Economics \& Management Sciences", Vol. 3, No. 3, pp. 1-7.

[5] Azmi F. (2008), Mapping the Learn-Unlearn-Relearn Model: Imperatives for Strategic Management, „European Business Review", Vol. 20, No. 3, pp. 240-259.

[6] Becker K. (2005), Individual and Organisational Unlearning: Directions for Future Research, „International Journal of Organisational Behaviour”, Vol. 9, No. 7, pp. 659-670.

[7] Becker K. (2007), Unlearning in the Workplace: A Mixed Methods Study, PhD thesis, Queensland University of Technology.

[8] Becker K. (2008), Unlearning as a Driver of Sustainable Change and Innovation: Three Australian Case Studies, „International Journal of Technology Management", Vol. 42, No. 1-2, pp. 89-106.

[9] Becker K. (2010), Facilitating Unlearning During Implementation of New Technology, ,Journal of Organizational Change Management", Vol. 23, No. 3, pp. 251-268.

[10] Becker K. (2018), Organizational Unlearning: Time to Expand our Horizons? „Learning Organization”, Vol. 25, No. 3, pp. 180-189.

[11] Burkšienė V. (2016), Unlearning and Forgetting for Sustainable Development of Contemporary Organizations: Individual Level, „Management of Organizations: Systematic Research", Vol. 75, pp. 25-40.

[12] Casillas J.C., Acedo F.J., Barbero J.L. (2010), Learning, Unlearning and Internationalisation: Evidence from the Pre-export Phase, „International Journal of Information Management", Vol. 30, No. 2, pp. 162-173.

[13] Cegarra-Navarro J.G., Dewhurst F.W. (2006), Linking Shared Organizational Context and Relational Capital through Unlearning: An Initial Empirical Investigation in SMEs, „The Learning Organization", Vol. 13, No. 1, pp. 49-62.

[14] Cegarra-Navarro J.G., Sánchez-Polo M.T. (2008a), Linking the Individual Forgetting Context with Customer Capital from a Seller's Perspective, "Journal of the Operational Research Society”, Vol. 59, No. 12, pp. 1614-1623.

[15] Cegarra-Navarro J.G., Sánchez-Polo M. (2008b), Linking Unlearning and Relational Capital through Organisational Relearning, „International Journal of Human Resources Development and Management", Vol. 7, No. 1, pp. 1-27.

[16] Cegarra-Navarro J.G., Cegarra-Leiva D., Sánchez-Vidal M.E., Wensley A.K.P. (2015), Congenital Learning, Organisational Performance and Work-life Balance Culture, „Knowledge Management Research and Practice”, Vol. 13, No. 1, pp. 1-31. 
[17] Cegarra-Navarro J.G., Martinez-Martinez A., Gutiérrez J.O., Rodríguez A.L.L. (2013), Environmental Knowledge, Unlearning, and Performance in Hospitality Companies, „Management Decision”, Vol. 51, No. 2., pp. 1-33.

[18] Cegarra-Navarro J.G., Wensley A.K.P., Polo, M.T.S. (2014), A Conceptual Framework for Unlearning in a Homecare Setting, „Knowledge Management Research \& Practice”, Vol. 12, No. 4, pp. 375-386.

[19] Cegarra-Navarro J.G., Cepeda-Carrión G., Eldridge S. (2011), Balancing Technology and Physician-Patient Knowledge through an Unlearning Context, „International Journal of Information Management", Vol. 31, No. 5, pp. 420-427.

[20] Cegarra-Navarro J.G., Sánchez-Vidal M.E., Cegarra-Leiva D. (2016), Linking Unlearning with Work-Life Balance: An Initial Empirical Investigation into SMEs, „Journal of Small Business Management”, Vol. 54, No. 1, pp. 373-391.

[21] Cegarra-Navarro J.G., Wensley A. (2019), Promoting Intentional Unlearning through an Unlearning Cycle, „Journal of Organizational Change Management", Vol. 32, No. 1, pp. 67-79.

[22] Cepeda-Carrión G., Cegarra-Navarro J.G., Martínez-Caro E., Eldridge S. (2011), How Can Managers in the Hospital in the Home Units Help to Balance Technology and Physician-Patient Knowledge? „International Journal for Quality in Health Care: Journal of the International Society for Quality in Health Care", Vol. 23, No. 5, pp. 600-609.

[23] Cepeda-Carrion G., Navarro J.G.C., Martinez-Caro E. (2012), Improving the Absorptive Capacity through Unlearning Context: An Empirical Investigation in Hospital-in-the-Home Units, „The Service Industries Journal”, Vol. 32, No. 9, pp. 1551-1570.

[24] de Holan P.M. (2011), Organizational Forgetting, Unlearning, and Memory Systems, „Journal of Management Inquiry", Vol. 20, No. 3, pp. 302-304.

[25] Grisold T., Kaiser A., Hafner J. (2017), Unlearning before Creating New Knowledge: A Cognitive Process, [in:] R.H. Sprague (ed.), Proceedings of the Fiftieth Annual Hawaii International Conference on System Sciences, IEEE Computer Society Press Waikoloa, pp. 3-27.

[26] Dixon N.M. (1992), Organizational Learning: A Review of the Literature with Implications for HRD Professionals. „Human Resource Development Quarterly”, Vol. 3, No. 1, pp. 29-49.

[27] Easterby-Smith M., Lyles M.A. (2011), In Praise of Organizational Forgetting, „Journal of Management Inquiry”, Vol. 20, No. 3, pp. 311-316.

[28] Fernandez Vicenc S.A. (2009), Organizational Forgetting and its Causes and Empirical Research, „Journal of Organizational Change Management", Vol. 22, No. 6, pp. 620-634.

[29] Fetters M.D., Molina-Azorin J.F. (2017), The Journal of Mixed Methods Research Starts a New Decade: The Mixed Methods Research Integration Trilogy and Its Dimensions, „Journal of Mixed Methods Research”, Vol. 11, No. 3, pp. 291-307.

[30] de Holan P.M., Nelson P. (2004), Remembrance of Things Past? The Dynamics of Organizational Forgetting, „Management Science", Vol. 50, No. 11, pp. 1603-1613.

[31] Hamel G., Prahalad C.K. (1993), Strategy as Stretch and Leverage, „Harvard Business Review”, Vol. 71, No. 2, pp. 75-84.
[32] Hedberg B. (1981), How Organizations Learn and Unlearn, [in:] P.C. Nystrom, W.H. Starbuck (eds.), Handbook of Organizational Design, Oxford University Press, New York, pp. 3-27.

[33] Hislop D., Bosley S., Coombs C.R., Holland J. (2013), The Process of Individual Unlearning: A Neglected Topic in an Under-researched Field, „Management Learning”, Vol. 45, No. 5, pp. 540-560.

[34] Huber G. (1991), Organizational Learning: The Contributing Processes and the Literatures, „Organization Science”, Vol. 2, No. 1, pp. 88-115.

[35] Klammer A., Grisold T., Nguyen N. (2019), Guest Editorial, „Learning Organization, Vol. 26, No. 5, pp. 445-453.

[36] Klammer A., Gueldenberg S. (2019), Unlearning and Forgetting in Organizations: A Systematic Review of Literature, „Journal of Knowledge Management”, Vol. 23, No. 5, pp. 860-888.

[37] Kluge A., Schüffler A.S., Thim C., Haase J., Gronau N. (2019), Investigating Unlearning and Forgetting in Organizations: Research Methods, Designs and Implications, „The Learning Organization", Vol. 26, No. 5, pp. 518-533.

[38] Leal-Rodríguez A.L., Eldridge S., Roldán J.L., Leal-Millán A.G., Ortega-Gutiérrez J. (2015), Organizational Unlearning, Innovation Outcomes, and Performance: The Moderating Effect of Firm Size, „Journal of Business Research”, Vol. 68, No. 4, pp. 803-809.

[39] Lee L.T.-S., Sukoco B.M. (2011), Reflexivity, Stress, and Unlearning in the New Product Development Team: the Moderating Effect of Procedural Justice, „R\&D Management”, Vol. 41, No. 4, pp. 410-423.

[40] Leonard-Barton D. (1992), Core Capabilities and Core Rigidities: A Paradox in Managing New Product Development, „Strategic Management Journal”, Vol. 13, No. 1, pp. 111-125.

[41] Lyu C., Yang J., Zhang F., Teo T.S.H., Guo W. (2020), Antecedents and Consequence of Organizational Unlearning: Evidence from China, „Industrial Marketing Management”, Vol. 84, pp. 261-270.

[42] Martelo-Landroguez S., Albort-Morant G., Leal-Rodríguez A.L., Ribeiro-Soriano B. (2018), The Effect of Absorptive Capacity on Green Customer Capital under an Organizational Unlearning Context, „Sustainability”, Vol. 10, No. 1, pp. 1-20.

[43] McKeown I. (2012), Teaching Old Dogs New Tricks: Why Unlearning Matters in SMEs, „The International Journal of Entrepreneurship and Innovation", Vol. 13, No. 1, pp. 25-34.

[44] Meziaz J., Grinyer P., Guth W. (2001), Changing Collective Cognition: A Process Model for Strategic Change, „Long Range Planning", Vol. 34, No. 1, pp. 71-95.

[45] Mieres C., López Sánchez J.Â., Santos-Vijande M.L. (2012), Internal Marketing, Innovation and Performance in Business Services Firms: The Role of Organizational Unlearning, „International Journal of Management”, Vol. 29, No. 4, pp. 403-429.

[46] Moher D., Liberati A., Tetzlaff J.A.D. (2009), Preferred Reporting Items for Systematic Reviews and MetaAnalyses: The PRISMA Statement, „PLoS Med”, Vol. 6, No. 7, e1000097.

[47] Navarro J.G.C., Moya B.R. (2005), Business Performance Management and Unlearning Process, „Knowledge and Process Management", Vol. 12, No. 3, pp. 161-170.

[48] Nystrom P.C., Starbuck W.H. (1984), To Avoid Organizational Crises, Unlearn, „Organizational Dynamics”, Vol. 12, No. 4, pp. 53-65. 
[49] Ortega-Gutierrez J., Cegarra J., Cepeda-Carrión G., Rodríguez A. (2015), Linking Unlearning with Quality of Health Services through Knowledge Corridors, „Journal of Business Research”, Vol. 68, No. 4, pp. 815-822.

[50] Peschl M.F. (2019), Unlearning Towards an Uncertain Future: On the Back end of Future-Driven Unlearning, „The Learning Organization”, Vol. 26, No. 5, pp. 454-469.

[51] Pighin M., Marzona A. (2011), Unlearning/Relearning in Processes of Business Information Systems Innovation, „Journal of Information and Organizational Sciences”, Vol. 35, No. 1, pp. 59-72.

[52] Quintero-Ramírez S., Ruiz-Castañeda W.L., Robledo-Velásquez J. (2017), Representation of Unlearning in the Innovation Systems: A Proposal from Agent-Based Modelin, „Estudios Gerenciales”, Vol. 33, No. 145, pp. 366-376.

[53] Rezazade Mehrizi M.H., Lashkarbolouki M. (2016), Unlearning Troubled Business Models: From Realization to Marginalization, „Long Range Planning”, Vol. 49, No. 3, pp. 298-323.

[54] Ruiz M.D.A., Gutiérrez J.O., Martinez-Caro E., Cegarra-Navarro J.G. (2017), Linking on Unlearning Context with Firm Performance trough Human Capital, „European Research on Management and Business Economics”, Vol. 23, No. 1, 16-22.

[55] Scheaffer Z., Mano-Negrin R. (2003), Executives' Orientations and Reactions to Organizational Crises, „Journal of Management Studies", Vol. 2, No. 2, pp. 573-606.

[56] Serenko A., Bontis N. (2017), Global Ranking of Knowledge Management and Intellectual Capital Academic Journals: 2017 Update, „Journal of Knowledge Management”, Vol. 21, No. 3, pp. 675-692.

[57] Sherwood D. (2000), The Unlearning Organisation, „Business Strategy Review", Vol. 11, No. 3, pp. 31-40.

[58] Sinkula J.M. (2002). Market-Based Success, Organizational Routines, and Unlearning, „Journal of Business and Industrial Marketing", Vol. 17, No. 4, pp. 253-269.

[59] Starbuck W.H. (2017), Organizational Learning and Unlearning, „Learning Organization”, Vol. 24, No. 1, pp. 30-38.

[60] Tranfield D., Denyer D., Smart P. (2003), Towards a Methodology for Developing Evidence-Informed Management Knowledge by Means of Systematic Review, „British Journal of Management", Vol. 14, No. 3. pp. 207-222.

[61] Tsang E.W.K. (2017), How the Concept of Organizational Unlearning Contributes to Studies of Learning Organizations: A Personal Reflection, "Learning Organization”, Vol. 24 No. 1, pp. 39-48.

[62] Tsang E.W.K., Zahra S.A. (2008), Organizational Unlearning, „Human Relations”, Vol. 61, No. 10, pp. 1435-1462.

[63] Volland M. (2019), How to Intentionally Forget Rules in Newly Introduced Agile Projects: A Case Study of a Multinational Automotive Company, „The Learning Organization”, Vol. 26 No. 5, pp. 470-484.

[64] Wang X., Lu Y., Zhao Y., Gong S., Li B. (2013), Organisational Unlearning, Organisational Flexibility and Innovation Capability: An Empirical Study of SMEs in China, „International Journal of Technology Management", Vol. 61, No. 2, pp. 132-155.

[65] Wang X., Xi Y., Xie J., Zhao Y. (2017), Organizational Unlearning and Knowledge Transfer in Cross-border M\&A: The Roles of Routine and Knowledge Compatibility, „Journal of Knowledge Management”, Vol. 21, No. 6, pp. 1580-1595.
[66] Wensley A.K.P., Cegarra-Navarro J.G. (2015), Overcoming Knowledge Loss through the Utilization of an Unlearning Context, „Journal of Business Research”, Vol. 68, No. 7, pp. 1563-1569.

[67] Wong P.S.P., Lam K.Y. (2012), Facing Turbulence: Driving Force for Construction Organizations to Regain Unlearning and Learning Traction, „Journal of Construction Engineering and Management", Vol. 138, No. 10, pp. 1201-1211.

[68] Xiangyang W., Yujuan X., Jingsi X., Yingxin Z. (2017), Organizational Unlearning and Knowledge Transfer in Cross-border M↔A: The Roles of Routine and Knowledge Compatibility, ,Journal of Knowledge Management”, Vol. 21, No. 6, pp. 1580-1595.

[69] Yang K.P., Chou C., Chiu Y.J. (2014), How Unlearning Affects Radical Innovation: The Dynamics of Social Capital and Slack Resources, „Technological Forecasting and Social Change", Vol. 87, pp. 152-163.

[70] Yildiz H.E., Fey C.F. (2010), Compatibility and Unlearning in Knowledge Transfer in Mergers and Acquisitions, „Scandinavian Journal of Management”, Vol. 26, No. 4, pp. 448-456.

[71] Zhao Y., Lu Y., Wang X. (2013), Organizational Unlearning and Organizational Relearning: A Dynamic Process of Knowledge Management, „Journal of Knowledge Management", Vol. 17, No. 6, pp. 902-912.

[72] Zhao Y., Wang X. (2020), Organisational Unlearning, Relearning and Strategic Flexibility: From the Perspective of Updating Routines and Knowledge, „Technology Analysis \& Strategic Management", Vol. 32, No. 11, pp. 1-13.

\section{Organizational Unlearning Research Agenda}

\section{Summary}

Unpredictable social, economic or technical phenomena occur in the organizational environment. In such a changing environment, employing well-established management practices by organizations becomes insufficient and even harmful. In response, organizations reject previously adopted procedures, knowledge, norms, and values to make room for the new ones. The aim of the article is to identify emerging directions of research into organizational unlearning. To identify the existing research axes, a systematic literature review was carried out. On this basis, the following five directions of the research on organizational unlearning have been identified: (1) identification of conditioning and strengthening factors; (2) including three levels in the study: individual, group and organizational; (3) recognising the importance of organizational unlearning for organizational learning; (4) recognising the importance of management in organizational unlearning; (5) recognising the importance of organizational unlearning for the implementation of technological innovations.

\section{Keywords}

organizational unlearning, research, systematic literature review 